\title{
Microhabitat use, population densities, and size distributions of sulfur cave-dwelling Poecilia mexicana
}

The Cueva del Azufre in Tabasco, Mexico, is a nutrient-rich cave and its inhabitants need to cope with high levels of dissolved hydrogen sulfide and extreme hypoxia. One of the successful colonizers of this cave is the poeciliid fish Poecilia mexicana, which has received considerable attention as a model organism to examine evolutionary adaptations to extreme environmental conditions. Nonetheless, basic ecological data on the endemic cave molly population are still missing; here we aim to provide data on population densities, size class compositions and use of different microhabitats. We found high overall densities in the cave and highest densities at the middle part of the cave with more than 200 individuals per square meter. These sites have lower $\mathrm{H}_{2} \mathrm{~S}$ concentrations compared to the inner parts where most large sulfide sources are located, but they are annually exposed to a religious harvesting ceremony of local Zoque people called La Pesca. We found a marked shift in size/age compositions towards an overabundance of smaller, juvenile fish at those sites. We discuss these findings in relation to several environmental gradients within the cave (i.e., differences in toxicity and lighting conditions), but we also tentatively argue that the annual fish harvest during a religious ceremony (La Pesca) locally diminishes competition (and possibly, cannibalism by large adults), which is followed by a phase of overcompensation of fish densities. 
1 Jonas Jourdan ${ }^{1,2^{*}}$, David Bierbach ${ }^{3}$, Rüdiger Riesch ${ }^{4}$, Angela Schieß1 ${ }^{1}$, Adriana Wigh ${ }^{1}$, Lenin

2 Arias-Rodriguez ${ }^{5}$, Jeane Rimber Indy ${ }^{5}$, Sebastian Klaus ${ }^{1}$, Claudia Zimmer ${ }^{1}$ and Martin Plath ${ }^{1}$

$3{ }^{1}$ Evolutionary Ecology Group, Goethe University of Frankfurt, Max-von-Laue-Straße 13, D-60438 Frankfurt am 4 Main, Germany

$5 \quad{ }^{2}$ Biodiversity and Climate Research Centre $\left(B i K^{F}\right)$, Senckenberganlage 25, 60325 Frankfurt am Main, Germany.

$6{ }^{3}$ Leibniz-Institute of Freshwater Ecology and Inland Fisheries, Müggelseedamm 310, D-12587 Berlin, Germany

$7 \quad{ }^{4}$ Department of Animal and Plant Sciences, University of Sheffield, Western Bank, Sheffield S10 2TN, UK

$8 \quad{ }^{5}$ División Académica de Ciencias Biológicas, Universidad Juárez Autónoma de Tabasco (UJAT), C.P. 86150

9 Villahermosa, Tabasco, México

$10 *$ Corresponding author’s email: JonasJourdan@googlemail.com 


\section{Introduction}

12 Cave fishes are emerging as model systems to study regressive evolutionary processes like the

13 reduction of eyes and pigmentation that typically accompany the colonization of caves by

14 previously surface-dwelling species (Romero \& Green 2005; Jeffery 2009). For example, the

15 characid Astyanax mexicanus is a model organism for EvoDevo studies of cave evolution

16 (Wilkens 1988; Jeffery 2001; Jeffery 2009). The cave form of a Mexican live-bearing fish, the so-

17 called cave molly (Poecilia mexicana; Gordon \& Rosen 1962) has adapted to the vastly divergent

18 ecological conditions inside a South Mexican sulfide cave, the Cueva del Azufre (also referred to

19 as Cueva Villa Luz or Cueva de las Sardinas; Parzefall 1993; Parzefall 2001) Cave environments

20 are usually energy limited compared to photosynthetically based epigean habitats (Hüppop 2005)

21 and fish densities reported for several different cave systems are low, with often less than one

22 individual per $\mathrm{m}^{2}$ (Trajano 2001). In contrast, the Cueva del Azufre is a sulfidic, nutrient-rich

23 habitat due to chemoautotrophic primary production through sulfide oxidizing bacteria that utilize

24 the abundant hydrogen sulfide in the cave (Hose \& Pisarowicz 1999; Colaço et al. 2002;

25 Summers Engel 2005). Hydrogen sulfide is acutely toxic to most metazoans and leads to extreme

26 hypoxia in the water (Evans 1967; Bagarinao 1992). Beside the Cueva del Azufre, few other

27 sulfurous chemoautotrophic cave-ecosystem are described, such as Movile in Romania (Sarbu et

28 al. 1996), Frasassi in Italy (Flot et al. 2010) and Ayyalon in Israel (Por 2007). All of these caves

29 are inhabited by invertebrates - many of them endemic to the caves - that exploit this unusual

30 food web. The Cueva del Azufre is the only known chemoautotrophic cave ecosystem which is

31 inhabited by a vertebrate species (Plath \& Tobler 2010). However, due to its toxicity, hydrogen

32 sulfide requires energetically costly behavioral (i.e. actively avoiding microhabitats with high

33 levels of toxicity) and physiological adaptations (various forms of detoxification) by animals

34 exposed to it (Tobler et al. 2009; Riesch et al. 2010). As a result of the simultaneous action of two 
strong selective forces (permanent darkness and hydrogen sulfide), locally adapted P. mexicana populations in the Cueva del Azufre system have received considerable scientific interest. The cave molly differs from its surface-dwelling ancestors in a distinct set of morphological, physiological, behavioral, and life-history traits; e.g., cave mollies have reduced eye size and reduced pigmentation, and females have a reduced fecundity combined with an increase in individual offspring size (Parzefall 2001; Tobler et al. 2008a; Riesch et al. 2010; Tobler et al. 2011b). Although the cave molly has been established as a model to examine evolutionary adaptations to extreme environmental conditions, population densities have not yet been quantified in the Cueva del Azufre system, which makes interpretation of some of the ecological and evolutionary data difficult with regards to how they influence long-term stability of the systems and population dynamics.

The Cueva del Azufre drains into the El Azufre, a sulfidic surface creek, which eventually joins the Río Oxolotán. The Cueva del Azufre and El Azufre differ dramatically in the composition of fish communities compared to adjacent non-sulfidic surface habitats. Poecilia mexicana occurs as the single dominant species in both systems. Only one further fish species, the predatory cichlid 'Cichlasoma'salvini occurs in the upper parts of the El Azufre, but only in small numbers. In downstream areas of the El Azufre where $\mathrm{H}_{2} \mathrm{~S}$ in not measurable, Heterandria bimaculata and Xiphophorus hellerii (Poeciliidae), Astyanax aeneus (Characidae) as well as "Cichlasoma" salvini and Thorichtys helleri (Cichlidae) occur (Plath \& Tobler 2010). In surrounding non-sulfidic surface habitats, diverse fish communities can be found, often dominated by cichlid and poeciliid species (Tobler et al. 2006; Plath \& Tobler 2010). In the Clear Creek, a small stream that is directly connected to El Azufre, H. bimaculata occurs at a high abundance together with small numbers of $X$. hellerii and $P$. mexicana. A reduced species diversity and dominance of a few specialists have been documented from other caves (Trajano 2001) and other sulfidic habitats (Tobler et al. 2008d). 
Little is known about anthropogenic disturbances on the population ecology of $P$. mexicana inhabiting the Cueva del Azufre. Today, the system is increasingly influenced by a growing number of visitors which reach their peak during a traditional annual ceremony of the local indigenous Zoque people named 'La Pesca'. The Cueva del Azufre is sacred to the Zoque people, and once a year, on the first Sunday of Easter week, the Zoque enter the cave and introduce rotenone- and deguelin-containing barbasco roots (Lonchocarpus sp., Fabaceae) into the water. Rotenone is an inhibitor of the mitochondrial complex-I of the respiratory chain, causing reduced cellular respiration (Singer \& Ramsay 1994). Barbasco is introduced into the water in the middle portion of the cave, therefore only downstream cave chambers are affected (Fig. 1). Capture of poisoned cave fish is facilitated by the anesthetic effect of barbasco, as narcotized fish are flushed out of the cave, where they are harvested using wooden baskets, and afterwards cooked and eaten as part of a religious ceremony honoring the Rain Gods (Tobler et al. 2011a). The yield of the annual harvest is considered to be indicative of the quality of the subsequent crop harvest ( $\underline{\text { Hose \& Pisarowicz 1999; }}$ Tobler et al. 2011a). Annual harvests amount to several thousand individuals, and the ceremony is likely to have taken place for centuries (Hose \& Pisarowicz 1999), so it is likely to act as a strong selective force on P. mexicana populations annually exposed to it.

In the present study, we provide first data of local densities within different chambers of the Cueva del Azufre and adjacent El Azufre and discuss our findings with regard to environmental conditions and annual harvesting of cave mollies. We used a non-invasive technique to repeatedly assess fish densities and size-distribution patterns (as a proxy for age) inside the Cueva del Azufre (up- and downstream of the barbasco-release site) and in the sulfidic creek leaving the cave (El Azufre). Moreover, given the high structural heterogeneity of the water course inside the Cueva del Azufre with respect to water depth and flow velocity ( Pisarowicz 1999), and because Croft et al. (2004) reported on size-specific preferences regarding 
water depth in another poeciliid, the Trinidadian guppy (P. reticulata), we combined our assessment of fish densities with an investigation of microhabitat use by different size classes of cave mollies.

\section{Material and Methods}

\section{Study system}

Locally adapted subterranean populations of P. mexicana (Fig. 1A) can be found in at least two different limestone caves in the vicinity of the southern Mexican city of Tapijulapa (state of Tabasco, México): the Cueva del Azufre (Gordon \& Rosen 1962) and the much smaller, nonsulfidic Cueva Luna Azufre (Tobler et al. 2008c). The sulfidic Cueva del Azufre is about 500 $600 \mathrm{~m}$ deep and divided into 13 different cave chambers (I-XIII), with the innermost chamber being XIII (Gordon \& Rosen 1962). Several springs discharge water with high concentrations of hydrogen sulfide $\left(\mathrm{H}_{2} \mathrm{~S}\right)$ into the creek draining the cave (Tobler et al. 2006). The cave creek forms a highly heterogeneous mosaic of shallow pools and backwaters that are partially divided by swift flowing riffle passages (Gordon \& Rosen 1962; Hose \& Pisarowicz 1999). While the front cave chambers receive some dim light through cracks in the ceiling, the inner parts of the cave are lightless. Consequently, (sub-)populations experience divergent selection regimes regarding light exposure, with populations from the innermost chambers living under perpetually dark conditions, whereas those from front chambers are exposed to dim sunlight through a number of cracks in the cave ceiling, so-called sky lights (Fontanier \& Tobler 2009).

Upon leaving the underground, the sulfidic creek draining the Cueva del Azufre is called 'El Azufre'. After meandering for approximately $1.5 \mathrm{~km}$, it eventually drains into the Río Oxolotán, which is part of the Río Grijalva drainage system. Despite the gradual oxidation of $\mathrm{H}_{2} \mathrm{~S}$ to sulfate and elemental sulfur with increasing distance from the sulfide sources, which increases 

the water turbidity, and despite the influx of some smaller clear water affluents, El Azufre still has a remarkably high $\mathrm{H}_{2} \mathrm{~S}$ concentration of up to $\sim 40 \mu \mathrm{Mol}$ (Tobler et al. 2006; $\underline{\text { Schlupp et al. 2013 }}$ ).

\section{Study sites and data collection}

We compared the abundance and distribution of different size classes of $P$. mexicana among different sampling sites along a transect starting at chamber $\mathrm{X}$ in the Cueva del Azufre, and following the water flow outside the cave to the confluence of El Azufre with the first freshwater influx from the Clear Creek. This transect, therefore, covered sample sites located upstream of the release point of barbasco during La Pesca (sample point in chamber X) and sites directly downstream of the release point of barbasco that are strongly affected by the annual ceremony (three sites in chamber V; CV-1, CV-2, and CV-3; Fig. 2A-B). Surface sites of El Azufre are also annually exposed to barbasco due to downstream effects (EA-ex, EA-mf), even though concentrations are probably considerably lower than inside the cave (Table 1). Clear creek (CC) and its confluence with EA (EA-con; Fig. 2C), on the other hand, are not influenced by barbasco. Field work was conducted in January 2010, i.e., about 9 month after the latest La Pesca ceremony in 2009 (L. Arias-Rodriguez, pers. obs.). At each of the eight sample sites, we defined sampling grids consisting of $50 \times 50 \mathrm{~cm}$ quadrants with wooden sticks fixed in the ground (or stones where a grid angle fell on the shore). The number of quadrants was mostly 25 per sampling grid (i.e., $5 \times 5$ quadrants). In the narrow non-sulfidic surface creek $(\mathrm{CC})$, however, the arrangement of quadrants was more longitudinal ( $4 \times 7=28$ quadrants), and in chamber $\mathrm{V}$, where a particularly high degree of structural heterogeneity precluded defining larger grids, one sampling site of $5 \times 5$ quadrants and two smaller ones (15 and 8 quadrants, respectively) were defined (Table 1). The grids reflected the natural variation in water depth, flow velocity, and substrate types, thus covering the range of different microhabitats inhabited by mollies (an example is shown in Fig. 3). 
133 least 5 times (mean $\pm \mathrm{SD}=6.25 \pm 1.16)$ on consecutive days. During the counts, we slowly 134 approached a site while trying to avoid any movements that would cause the resident fish to flee, and we counted juveniles $(<10 \mathrm{~mm}$ standard length $(\mathrm{SL}))$, sub-adults $(10-30 \mathrm{~mm})$ and adults $(>$ $30 \mathrm{~mm}$ ) in each quadrant. The observer was standing motionless at least $1.5 \mathrm{~m}$ downstream from the respective quadrant. Sizes were estimated qualitatively, aided by a prior training session that used wooden sticks of known size as a reference. Our definition of adults roughly followed Riesch et al. (2010), who determined the mean $( \pm \mathrm{SD})$ standard length of reproducing females to be $31.44 \pm 4.40 \mathrm{~mm}$ (El Azufre) and $36.97 \pm 4.59 \mathrm{~mm}$ (Cueva del Azufre, chambers V and X). Habitat parameters were assessed after the last fish count. For each quadrant, we determined water depth using a wooden ruler stuck vertically into the water at five random locations and calculating the mean from those five measurements. Flow velocity was measured on the water surface by scoring the time a small wooden stick of about $3 \mathrm{~cm}$ length took to float through the whole length of a quadrant (measurement was repeated five times per quadrant and averaged across the five observations per quadrant). Mean surface flow velocity was then expressed as $\mathrm{cm}^{*} \mathrm{~s}^{-1}$. Research followed the authorizations from CONAPESCADGOPA.09004.041111.3088 and Tacotalpa, Tabasco municipality.

\section{Statistical analysis}

Our first question was whether population densities differed among sampling sites. We used data for the different quadrants per site (averaged from the repeated measurements) and expressed density as total numbers of individuals per square meter. Density estimates per quadrant were used as the dependent variable in a univariate general linear model (GLM) with 'sampling site' as a fixed factor. We initially entered 'mean water depth' $\left(F_{1,162}=0.12, P=0.98\right)$ and 'mean flow rate' $\left(F_{1,162}=0.22, P=0.64\right)$ as covariates, but removed them from the final analysis since neither 
had a significant effect (also none of the interaction terms were significant). We used Fisher's LSD tests for pairwise post hoc comparisons among sites.

A further question was whether size-class compositions differed among sample sites and whether distribution patterns would be stable among repeated sampling days. We used the BrayCurtis index (Bray \& Curtis 1957) to estimate pairwise similarities among each sampling point (calculated with the R-package 'ecodist 1.2.7'; Goslee and Urban 2012; R Development Core Team 2008), and used these for non-metric multidimensional scaling ('NMDS PROXSCAL' function in SPSS 21). To detect clusters, we used the 'two step cluster analysis' function based on Euclidian distances and the Bayesian information criterion. For visualization of size class compositions per site, we averaged repeated measurements of different size classes and used a mean value for each quadrant per site. By using this means we calculated the total average size class distribution per site.

Our first analysis detected pronounced variation in population densities and size distributions (see results) and thus, we decided to analyze potential effects of water depth and flow velocity (i.e., microhabitat choice) in a site-wise fashion. We focused on sites inside the Cueva del Azufre (CV-1, CV-3 and CX) where (a) fish densities were sufficiently high and $(b)$ sufficient variability of those environmental variables was found to allow for a meaningful analysis. All other sites were excluded from this analysis. For each site, fish density per quadrant was entered as the dependent variable in repeated measures (rm) GLMs with 'size class' (three levels $)$ as the repeated measurement. We grouped water depth $(<5 \mathrm{~cm}, 5-10 \mathrm{~cm},>10 \mathrm{~cm})$ and flow velocity $\left(<10 \mathrm{~cm}^{*} \mathrm{~s}^{-1}, 10-50 \mathrm{~cm}^{*} \mathrm{~s}^{-1},>50 \mathrm{~cm}^{*} \mathrm{~s}^{-1}\right)$ into three classes each and used these habitat parameters as fixed factors. However, neither the main factor 'flow velocity' nor any interaction term involving 'flow velocity' had a significant effect in any of the three site-specific models $\left(\mathrm{CV}-1: F_{4,38}=1.27, P=0.30 ; \mathrm{CV}-3: F_{2,4}=3.28, P=0.14 ; \mathrm{CX}: F_{2,20}=0.44, P=0.65\right)$, and so we subsequently removed this term from all models. 
181

\section{Results}

\section{Local population densities}

When comparing mean densities per quadrant across sites we detected a significant difference among sampling sites (GLM; $F_{7,164}=32.49, P<0.001$; Fig. 1B). Post hoc pairwise LSD tests found most pairwise comparisons to be statistically significant; qualitatively, densities increased from surface sites (mean $\pm \mathrm{SE}$ across sites $=21.0 \pm 5.0$ individuals $\left.* \mathrm{~m}^{-2}\right)$ towards the cave $(119.5$ \pm 12.7 individuals $* \mathrm{~m}^{-2}$ ). Also, sites downstream of the barbasco release-site (chamber $\mathrm{V} ; 162.3 \pm$ 16.1 individuals* $\mathrm{m}^{-2}$ ) had considerably higher densities than the site in chamber $\mathrm{X}$ that lies upstream of the release-site $\left(37.4 \pm 4.8\right.$ individuals $\left.* \mathrm{~m}^{-2}\right)$.

\section{Differences in size-class compositions}

The NMDS based on Bray-Curtis similarities found data from repeated sampling days to cluster together, suggesting that the observed size-class compositions were stable over the period of this study (Fig. 4). There were three distinct clusters, and in only one case was a single sampling day of a given sampling site assigned to the 'wrong' cluster. The first cluster comprised the three sample sites in cave chamber V and EA-con. Samples had high overall densities and were composed mostly of small individuals. Cluster two comprised the rearmost cave site CX. Samples in this cluster were characterized by intermediate densities but a particularly high proportion of large individuals. Cluster three comprised all surface sites except EA-con and was characterized by overall low densities and mostly intermediate-sized fish (Fig. 4).

\section{Microhabitat use of different size classes}


In the rmGLMs treating the different size-classes as the repeated measurement, the interaction term 'size-class $\times$ water-depth' had a significant effect for two of the three sampling sites included in this analysis - notably, those sites with the most variation in water depth (Fig. 5). This result is indicative of differences in microhabitat use among different size classes of cave mollies: generally, larger fish were found in deeper areas, whereas smaller fish resided in shallow parts. A significant main effect of the repeated measurement ('size class') in all three analyses confirms the overabundance of small-sized fish in cave chamber V, and of large-bodied fish in chamber X (Fig. 5).

\section{Discussion}

We provide detailed information on population densities of cave-adapted $P$. mexicana in the Cueva del Azufre. Repeated measurement in different cave chambers uncovered very stable patterns of high densities, confirming qualitative estimates provided by Parzefall (1993). Density estimates of $P$. mexicana in the cave were extraordinarily high and exceed those of other cave fishes, which are usually low, with often less than one individual per $\mathrm{m}^{2}$ (Trajano 2001). Furthermore, densities were higher inside the cave compared to adjacent surface populations. Variation in population densities can be explained by different factors affecting cave molly population dynamics; e.g., environmental heterogeneity may contribute to population differences. The highest $\mathrm{H}_{2} \mathrm{~S}$ concentrations $(>300 \mu \mathrm{M})$ are found in parts of chamber $\mathrm{X}$, where most large sulfide sources are located, while concentrations in chamber V are lower $(2-32 \mu \mathrm{M})$, as $\mathrm{H}_{2} \mathrm{~S}$ is increasingly bound with oxygen with increasing distance from the sulfide sources (Tobler et al. 2006). However, ecotoxicological experiments repeatedly found small adults to have higher $\mathrm{H}_{2} \mathrm{~S}$-resistance than large-bodied adults, possibly reflecting senescence effects or size-specific thresholds regarding the rate of sulfide influx to the body to oxidation (Tobler et al. 
2011b; Plath et al. 2013; Riesch et al. 2014). Hence, we would expect fish in chamber X to actually be smaller than fish from chamber $\mathrm{V}$ if different $\mathrm{H}_{2} \mathrm{~S}$ concentrations were the main driver of population differences.

Beside different $\mathrm{H}_{2} \mathrm{~S}$ concentrations, the sites within the cave differ in the presence of light. Whereas chamber $\mathrm{V}$ receive some dim light through cracks in the ceiling, the inner parts of the cave are lightless. Photophobic behavior is a factor that has been proposed to promote the colonization of perpetually dark caves and the choice of microhabitat (Poulson 1964; $\underline{\text { Barr Jr }}$ 1968). While photophobic behavior has been reported in several cavefishes (Wilkens 1988;

Camassa 2001; Wilkens 2001; Timmermann \& Plath 2009), photophilic behavior was found in both surface and cave forms of P. mexicana (Parzefall et al. 2007). In theory, this photophilic behavior could lead to an accumulation of fish in chamber V (sites 5-7) compared to chamber X (site 8 ) if fish moved between cave chambers but were less likely to return to dark sites, but this line of argumentation is not compatible with the observation of small-scale genetic structure among different cave chambers (Plath et al. 2007).

The different light regimes may also affect trophic interactions since the deep and lightless parts of the cave depend solely on chemoautotrophic primary production, while organic matter can enter through cracks in chamber $\mathrm{V}$, and then provide the basis for detritivore animal communities that constitute an additional food source in other cave systems (üppop 2005). Nevertheless, more research is needed on the extent to which these few sky lights might indeed provide significant influx of additional nutrients, because stomach content analysis of cave mollies, for example, does so far not strongly support such a notion (Poulson 1964; Barr Jr 1968; Tobler et al. 2009).

Furthermore, cave chambers may differ in predation regimes. Inside the Cueva del Azufre, aquatic water bugs of the genus Belostoma prey upon cave mollies and Belostoma prefer large over small cave mollies as prey (Tobler et al. 2007; Tobler et al. 2008b; Plath et al. 2011). Mark- 
recapture analysis found individual densities of water bugs to be approximately one individual per $\mathrm{m}^{2}$ in chamber $\mathrm{V}$ (Tobler et al. 2007), and while empirical data are as yet lacking, observational evidence over several years of field work suggests that densities are much lower in the innermost chambers.

Belostoma predation, however, might explain microhabitat use of different size classes of cave mollies. Belostoma are typically found on rocks at the water's edge (Tobler et al. 2008b), and so large cave mollies_- being preferred by the water bugs (Plath et al. 2011) — could use deeper parts of the water column to avoid predation risk. The preference for large size-classes

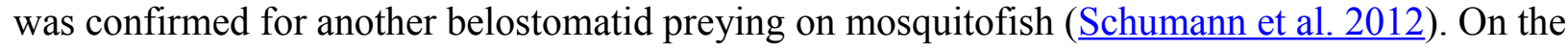
other hand, small fish could avoid filial cannibalism, which is known from other poeciliids (Loekle et al. 1982; Nesbit \& Meffe 1993), by using shallow parts of the water column that exclude large mature fish.

One factor that most likely influences population dynamics is the annual 'La Pesca' ceremony. The ceremony leads to a strong temporary reduction of local fish densities in those cave chambers that are situated downstream of the barbasco release site (Tobler et al. 2011a). Our study was conducted approximately nine months after the last ceremony, but given rather long generation times in P. mexicana (roughly 3-6 months for males and 7-10 months for females from birth until reaching maturation under common-garden rearing conditions; Riesch, Reznick, Plath \& Schlupp, submitted), we predicted to find lower (sub-)population densities and especially fewer large-bodied individuals downstream of the site in the Cueva del Azufre where barbasco is annually released. Instead, while fish densities were generally high in the cave, they were highest downstream of the barbasco release site. However, sample sites affected by the release of barbasco had population structures that were strongly shifted towards an overabundance of the smallest size classes (i.e., juveniles). These patterns were stable when repeated samplings from subsequent days were compared. 
among different cave chambers occurs only to a small extent, which results in population genetic

differentiation, as shown based on nuclear microsatellites (Plath et al. 2007), and is also reflected

in morphological differences among fish from different cave chambers (Fontanier \& Tobler

278 2009). Hence, re-colonization of the affected sites from other parts of the cave (i.e., source-sink dynamics) is unlikely, and the observed recovery of the respective populations likely represents an autochthonous effect. After the temporal decline in population density following La Pesca, the surviving individuals benefit from reduced intraspecific resource competition. Detritus and green algae are the dominant food sources of surface-dwelling $P$. mexicana from non-sulfidic streams, while diets of conspecifics in the sulfidic surface and cave streams are dominated by chemoautotrophic (sulfur) bacteria and aquatic invertebrates (like larvae of the dipteran Goeldichironomus fulvipilus and small snails; (Roach et al. 2011). In particular, access to invertebrate prey could be favored not only by the absence of competing fish species, but especially by temporarily relaxed competition among the surviving adult $P$. mexicana. Generally, relaxed competition translates into higher growth rates, faster maturation, and increased adult fecundity (Stearns 1976), which may lead to stage-specific biomass overcompensation, thereby compensating for the removal of individuals from the population (Werner \& Gilliam 1984; de

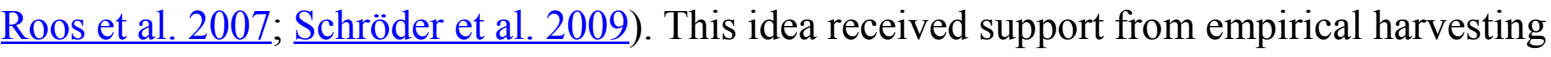
experiments that found the negative relationship between adult mortality and abundance/density to be reversed if mortality does not affect a certain portion of the population. Experimental studies on laboratory populations of the poeciliid fish Heterandria formosa showed that biomass of the juvenile size class increased in response to intermediate adult mortality rates (Schröder et al. 2009). Another study showed that a pathogen outbreak in a wild perch population (Perca

297 fluviatilis) was followed by a biomass overcompensation of the juvenile stage as a result of 298 increased adult mortality. Age-specific adult fecundity and body mass of one- and two year old 
perch increased after the disease outbreak, suggesting that increased adult mortality released perch from competition and cannibalism, thereby increasing somatic and reproductive growth (Ohlberger et al. 2011). In the Cueva del Azufre, the stage-specific biomass overcompensation may lead to increasing population densities, based on temporarily increased adult fecundity that leads to a high numbers of juvenile fish. This would result in cave molly populations regaining the high densities seen before La Pesca, again leading to increased competition. This is consistent with earlier observations of cave mollies showing reduced body condition (measured, e.g., as fat content) compared to fish from surface sites ( human-induced selection and predation by Belostoma ought to have very similar effects on the populations exposed to them. We are inclined to argue, however, that the relative influence of Belostoma predation is considerably lower than the effects of the massive annual fish harvest. Previous reports of increased rotenone-resistance in fish from chamber $\mathrm{V}$, but not chamber X (Tobler et al. 2011a), confirm that La Pesca undoubtedly has a strong selective influence on populations annually exposed to it.

In summary, we found remarkable fish densities of more than 200 individuals per $\mathrm{m}^{2}$ in some parts of the cave. While other selective forces certainly also need to be considered, we argue that the annual La Pesca has major effects on the population ecology and evolutionary trajectory of cave mollies. We are aware of potential caveats of this line of argumentation, as not all differences reported here may be due to the annual La Pesca ceremony. Nevertheless, from a conservational point of view, knowledge about whether and how human activities affect teleost populations is especially pertinent in the case of locally adapted populations that are endemic to a small area. Therefore, we recommend a repeated sampling before and after La Pesca in order to demonstrate the influence of the ritual. While human influences on highly endemic, locally adapted populations (or, in terms of conservation biology, evolutionary significant units; Moritz 1994) generally are to be evaluated as highly problematic, management plans for cave mollies 
ought to consider the important role La Pesca plays in the religion of the local human population.

Carried out in the traditional way, fish populations in downstream cave chambers can obviously recover after the ceremony. However, we wish to highlight the necessity to critically review that those practices do not affect deeper parts of the cave and that no commercially available, more efficient fish toxins will be employed in the future.

\section{Acknowledgements}

We thank J. Dzienko, N. Karau, A. Oranth and S. Stadler for their help in the field. Artwork (drawing of a cave molly female (Fig. 1A) was prepared by M. Ziege.

\section{References}

Bagarinao T. 1992. Sulfide as an environmental factor and toxicant: tolerance and adaptations in aquatic organisms. Aquatic Toxicology 24:21-62.

Barr Jr TC. 1968. Cave ecology and the evolution of troglobites. Evolutionary biology: Springer, 35-102.

Bray JR, and Curtis JT. 1957. An ordination of the upland forest communities of southern Wisconsin. Ecological monographs 27:325-349.

Camassa MM. 2001. Responses to light in epigean and hypogean populations of Gambusia affinis (Cyprinodontiformes : Poeciliidae). Environmental Biology of Fishes 62:115-118.

Colaço A, Dehairs F, and Desbruyeres D. 2002. Nutritional relations of deep-sea hydrothermal fields at the Mid-Atlantic Ridge: a stable isotope approach. Deep Sea Research Part I: Oceanographic Research Papers 49:395-412.

Croft DP, Botham MS, and Krause J. 2004. Is sexual segregation in the guppy, Poecilia reticulata, consistent with the predation risk hypothesis? Environmental Biology of Fishes 71:127-133.

de Roos AM, Schellekens T, van Kooten T, van de Wolfshaar KE, Claessen D, and Persson L. 2007. Food-dependent growth leads to overcompensation in stage-specific Biomass when mortality increases: The influence of maturation versus reproduction regulation. American Naturalist 170:E59-E76.

Evans CL. 1967. The toxicity of hydrogen sulphide and other sulphides. Quarterly Journal of Experimental Physiology and Cognate Medical Sciences 52:231-248.

Flot J-F, Wörheide G, and Dattagupta S. 2010. Unsuspected diversity of Niphargus amphipods in the chemoautotrophic cave ecosystem of Frasassi, central Italy. Bmc Evolutionary Biology 10:171.

Fontanier ME, and Tobler M. 2009. A morphological gradient revisited: cave mollies vary not only in eye size. Environmental Biology of Fishes 86:285-292.

Gordon MS, and Rosen DE. 1962. A cavernicolous form of the poeciliid fish Poecilia sphenops from Tabasco, Mexico. Copeia:360-368. 
Hose LD, and Pisarowicz JA. 1999. Cueva de Villa Luz, Tabasco, Mexico: Reconnaissance study of an active sulfur spring cave and ecosystem. Journal of Cave and Karst Studies 61:1321.

Hüppop K. 2005. Adaptation to low food. In: Culver DC, and White WB, eds. Encyclopedia of caves. Amsterdam: Elsevier, 4-10.

Jeffery WR. 2001. Cavefish as a model system in evolutionary developmental biology. Developmental Biology 231:1-12.

Jeffery WR. 2009. Regressive evolution in Astyanax cavefish. Annual review of genetics 43:25.

Loekle DM, Madison DM, and Christian JJ. 1982. Time dependency and kin recognition of cannibalistic behavior among poeciliid fishes. Behavioral and Neural Biology 35:315318.

Moritz C. 1994. Defining'evolutionarily significant units' for conservation. Trends in Ecology \& Evolution 9:373-374.

Nesbit DH, and Meffe GK. 1993. Cannibalism frequencies in wild populations of the eastern mosquitofish (Gambusia holbrooki: Poeciliidae) in South Carolina. Copeia 3:867-870.

Ohlberger J, Langangen Ø, Edeline E, Claessen D, Winfield IJ, Stenseth NC, and Vøllestad LA. 2011. Stage-specific biomass overcompensation by juveniles in response to increased adult mortality in a wild fish population. Ecology 92:2175-2182.

Parzefall J. 1993. Behavioral ecology of cave-dwelling fishes. In: Pitcher TJ, ed. Behavior of Teleost Fishes. London: Chapman \& Hall, 573 - 606.

Parzefall J. 2001. A review of morphological and behavioural changes in the cave molly, Poecilia mexicana, from Tabasco, Mexico. Environmental Biology of Fishes 62:263-275.

Parzefall J, Kraus C, Tobler M, and Plath M. 2007. Photophilic behaviour in surface- and cavedwelling Atlantic mollies Poecilia mexicana (Poeciliidae). Journal of Fish Biology 71:1225-1231.

Plath M, Hauswaldt JS, Moll K, Tobler M, De Leon FJG, Schlupp I, and Tiedemann R. 2007. Local adaptation and pronounced genetic differentiation in an extremophile fish, Poecilia mexicana, inhabiting a Mexican cave with toxic hydrogen sulphide. Molecular Ecology 16:967-976.

Plath M, Pfenninger M, Lerp H, Riesch R, Eschenbrenner C, Slattery PA, Bierbach D, Herrmann N, Schulte M, Arias-Rodriguez L, Indy JR, Passow C, and Tobler M. 2013. Genetic differentiation and selection against migrants in evolutionarily replicated extreme environments. Evolution 67:2647-2661.

Plath M, Riesch R, Culumber Z, Streit B, and Tobler M. 2011. Giant water bug (Belostoma sp.) predation on a cave fish (Poecilia mexicana): effects of female body size and gestational state. Evolutionary Ecology Research 13:133-144.

Plath M, and Tobler M. 2010. Subterranean fishes of Mexico (Poecilia mexicana, Poeciliidae). The Biology of Subterranean Fishes:283-332.

Por FD. 2007. Ophel: a groundwater biome based on chemoautotrophic resources. The global significance of the Ayyalon cave finds, Israel. Hydrobiologia 592:1-10.

Poulson TL. 1964. Animals in aquatic environments: animals in caves. In: Bill DB, ed. Handbook of Physiology, 749-771.

Riesch R, Plath M, and Schlupp I. 2010. Toxic hydrogen sulfide and dark caves: life-history adaptations in a livebearing fish (Poecilia mexicana, Poeciliidae). Ecology 91:1494-1505.

Riesch R, Plath M, and Schlupp I. 2011. Toxic hydrogen sulphide and dark caves: pronounced male life-history divergence among locally adapted Poecilia mexicana (Poeciliidae). Journal of Evolutionary Biology 24:596-606. 
Riesch R, Plath M, Schlupp I, Tobler M, and Brian Langerhans R. 2014. Colonisation of toxic environments drives predictable life-history evolution in livebearing fishes (Poeciliidae). Ecology Letters 17:65-71.

Roach KA, Tobler M, and Winemiller KO. 2011. Hydrogen sulfide, bacteria, and fish: a unique, subterranean food chain. Ecology 92:2056-2062.

Romero A, and Green S. 2005. The end of regressive evolution: examining and interpreting the evidence from cave fishes. Journal of Fish Biology 67:3-32.

Sarbu SM, Kane TC, and Kinkle BK. 1996. A chemoautotrophically based cave ecosystem. Science 272:1953-1955.

Schlupp I, Colston TJ, Joachim BL, and Riesch R. 2013. Translocation of cave fish (Poecilia mexicana) within and between natural habitats along a toxicity gradient. Ecology of Freshwater Fish 22:228-233.

Schröder A, Persson L, and de Roos AM. 2009. Culling experiments demonstrate size-class specific biomass increases with mortality. Proceedings of the National Academy of Sciences of the United States of America 106:2671-2676.

Schumann DA, Cavallaro MC, and Hoback WW. 2012. Size Selective Predation of Fish by Hydrophilis triangularis (Coleoptera: Hydrophilidae) and Lethocerus americanus (Hemiptera: Belostomatidae). Journal of the Kansas Entomological Society 85:155-159.

Singer TP, and Ramsay RR. 1994. The reaction sites of rotenone and ubiquinone with mitochondrial NADH dehydrogenase. Biochimica Et Biophysica Acta-Bioenergetics 1187:198-202.

Stearns SC. 1976. Life-history tactics: a review of the ideas. Quarterly review of biology 51:3-47. Summers Engel A. 2005. Chemoautotrophy. In: Culver DC, and White WB, eds. Encyclopedia of caves. Amsterdam: Elsevier, 90-102.

Timmermann M, and Plath M. 2009. Phototactic response and light sensitivity in an epigean and a hypogean population of a barb (Garra barreimiae, Cyprinidae). Aquatic ecology 43:539-547.

Tobler M, Culumber Z, Plath M, Winemiller K, and Rosenthal G. 2011a. An indigenous religious ritual selects for resistance to a toxicant in a livebearing fish. Biology letters 7:229-232.

Tobler M, DeWitt TJ, Schlupp I, García de León FJ, Herrmann R, Feulner PG, Tiedemann R, and Plath M. 2008a. Toxic hydrogen sulfide and dark caves: phenotypic and genetic divergence across two abiotic environmental gradients in Poecilia mexicana. Evolution 62:2643-2659.

Tobler M, Franssen CM, and Plath M. 2008b. Male-biased predation of a cave fish by a giant water bug. Naturwissenschaften 95:775-779.

Tobler M, Palacios M, Chapman LJ, Mitrofanov I, Bierbach D, Plath M, Arias-Rodriguez L, de Leon FJG, and Mateos M. 2011b. Evolution in extreme environments: replicated phenotypic differentiation in livebearing fish inhabiting sulfidic springs. Evolution 65:2213-2228.

Tobler M, Riesch R, de Leon FJG, Schupp I, and Plath M. 2008c. New and morphologically distinct population of cavernicolous Poecilia mexicana (Poeciliidae : Teleostei). Environmental Biology of Fishes 82:101-108.

Tobler M, Riesch R, Garcíade León F, Schlupp I, and Plath M. 2008d. Two endemic and endangered fishes, Poecilia sulphuraria (Alvarez, 1948) and Gambusia eurystoma Miller, 1975 (Poeciliidae, Teleostei) as only survivors in a small sulphidic habitat. Journal of Fish Biology 72:523-533.

Tobler M, Riesch RW, Tobler CM, and Plath M. 2009. Compensatory behaviour in response to sulphide-induced hypoxia affects time budgets, feeding efficiency, and predation risk. Evolutionary Ecology Research 11:935-948. 
Tobler M, Schlupp I, Heubel KU, Riesch R, de Leon FJG, Giere O, and Plath M. 2006. Life on the edge: hydrogen sulfide and the fish communities of a Mexican cave and surrounding waters. Extremophiles 10:577-585.

Tobler M, Schlupp I, and Plath M. 2007. Predation of a cave fish (Poecilia mexicana, Poeciliidae) by a giant water-bug (Belostoma, Belostomatidae) in a Mexican sulphur cave. Ecological Entomology 32:492-495.

Trajano E. 2001. Ecology of subterranean fishes: an overview. Environmental Biology of Fishes 62:133-160.

Werner EE, and Gilliam JF. 1984. The ontogenetic niche and species interactions in sizestructured populations. Annual Review of Ecology and Systematics 15:393-425.

Wilkens H. 1988. Evolution and genetics of epigean and cave Astyanax fasciatus (Characidae, Pisces). Evolutionary biology: Springer, 271-367.

Wilkens H. 2001. Convergent adaptations to cave life in the Rhamdia laticauda catfish group (Pimelodidae, Teleostei). The biology of hypogean fishes: Springer, 251-261. 


\section{Table 1 (on next page)}

List of sampling sites

Sampling sites, their abbreviation code as used throughout the article, numbers of quadrants examined, and details regarding barbasco release. 


\section{Tables}

\section{Table 1}

Sampling sites, their abbreviation code as used throughout the article, numbers of quadrants examined, and details regarding barbasco release.

\begin{tabular}{|c|c|c|c|c|}
\hline Site code & Site & $\begin{array}{l}\text { Number of } \\
\text { quadrants }\end{array}$ & $\begin{array}{l}\text { Affected by } \\
\text { deposition of } \\
\text { rotenone? }\end{array}$ & $\begin{array}{l}\text { Approximate distance to } \\
\text { upstream rotenone } \\
\text { release site }[\mathrm{m}]\end{array}$ \\
\hline 1 EA-con & $\begin{array}{l}\text { El Azufre, confluence with } \\
\text { Clear Creek }\end{array}$ & 25 & No (only partly) & 150 \\
\hline $2 \mathrm{CC}$ & Clear Creek & 28 & No & - \\
\hline 3 EA-mf & El Azufre, mudflat & 25 & Yes & 120 \\
\hline 4 EA-ex & $\begin{array}{l}\text { El Azufre, exit of the Cueva } \\
\text { del Azufre }\end{array}$ & 25 & Yes & 110 \\
\hline $5 \mathrm{CV}-1$ & $\begin{array}{l}\text { Cueva del Azufre, Chamber } \\
\text { V, site } 1\end{array}$ & 25 & Yes & 0 \\
\hline $6 \mathrm{CV}-2$ & $\begin{array}{l}\text { Cueva del Azufre, Chamber } \\
\text { V, site } 2\end{array}$ & 15 & Yes & 0 \\
\hline $7 \mathrm{CV}-3$ & $\begin{array}{l}\text { Cueva del AzufreChamber } \\
\text { V, site } 3\end{array}$ & 8 & Yes & 0 \\
\hline $8 \mathrm{CX}$ & $\begin{array}{l}\text { Cueva del Azufre, Chamber } \\
X\end{array}$ & 25 & No & - \\
\hline
\end{tabular}




\section{Figure 1}

Study system and population densities.

(A) Drawing of a female cave molly. (B) Map of the study area showing the different sampling sites (numbers) where white areas represent water within the cave (Cueva del Azufre) and dark areas indicate dry land and bedrock. 1 EA-con, 2 CC, 3 EA-mf, 4 EA-ex, 5 CV-1, 6 CV2, 7 CV-3, $8 \mathrm{CX}$. With the exception of sampling site CV-1 all sampling sites inside the Cueva del Azufre are completely dark. Barbasco is released annually between chamber $\mathrm{V}(\mathrm{CV})$ and chamber $X(C X)$. Three sampling sites inside chamber $V$ were defined (CV-1 to CV-3). Downstream of the exit of the Cueva del Azufre (EA-ex), a rather homogeneous mudflat (EAmf) was sampled. Further sampling sites were a small non-sulfidic creek (Clear Creek; CC) and its confluence with El Azufre (EA-con). (C) Mean ( \pm SE) densities of mollies at each sampling site. Letters above the error bars signify statistically different groups (Fisher's LSD tests). (D) Size class compositions of mollies at the different sampling sites. 
A.

B.

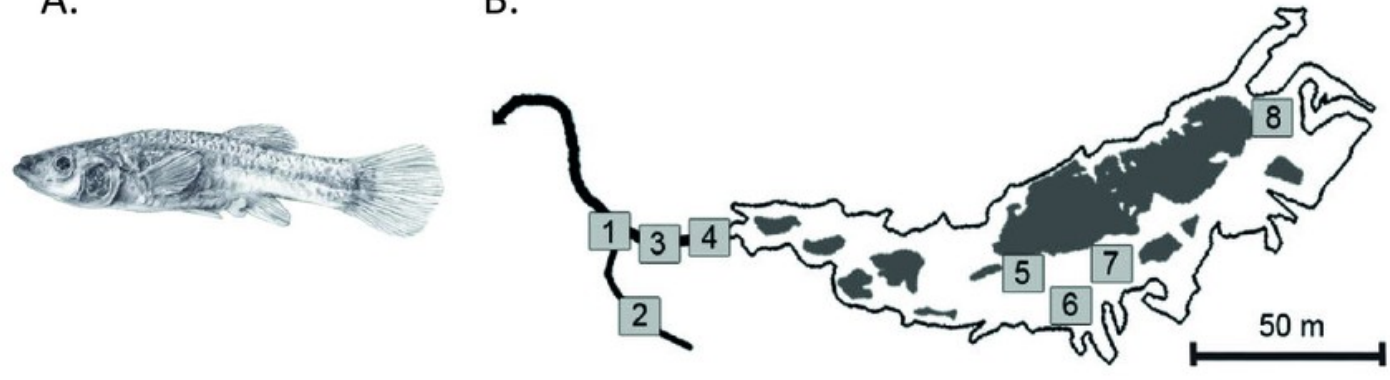

C. Densities

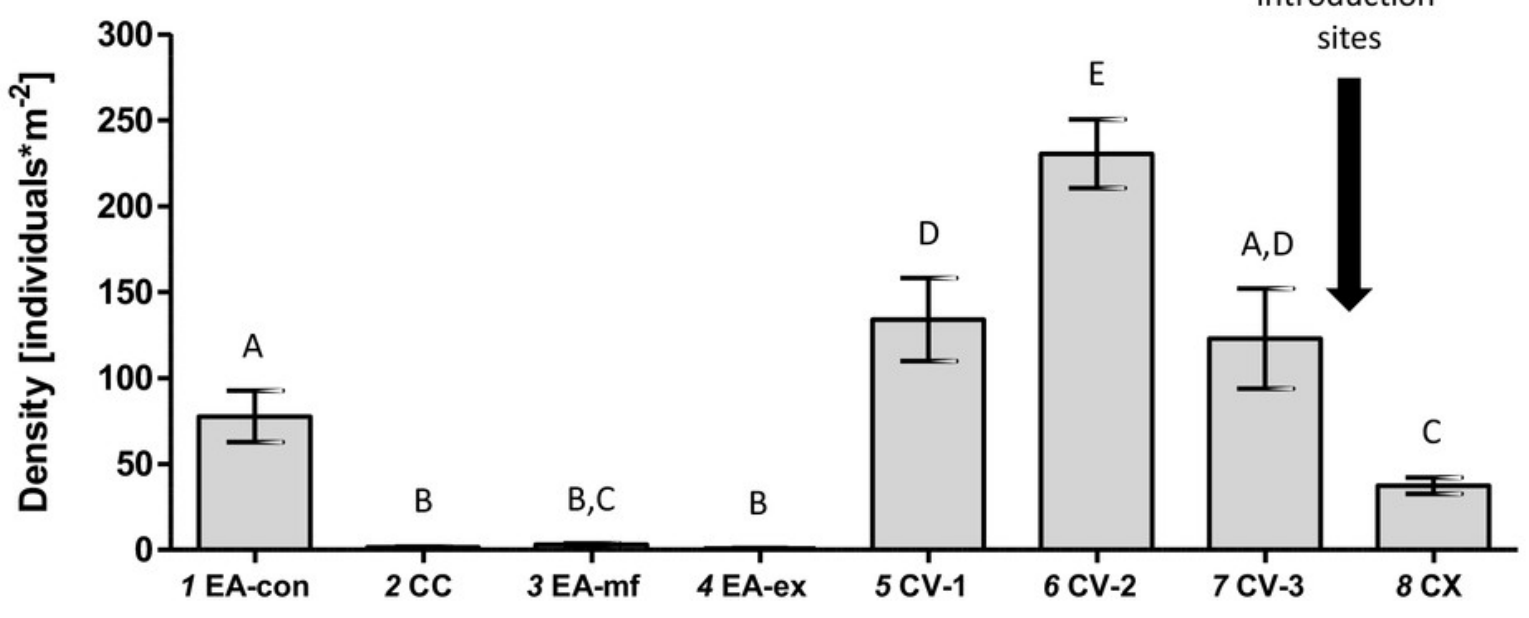

Barbasco introduction sites

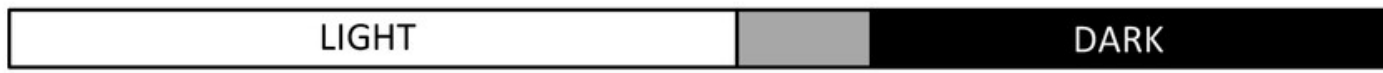

D. Size distributions
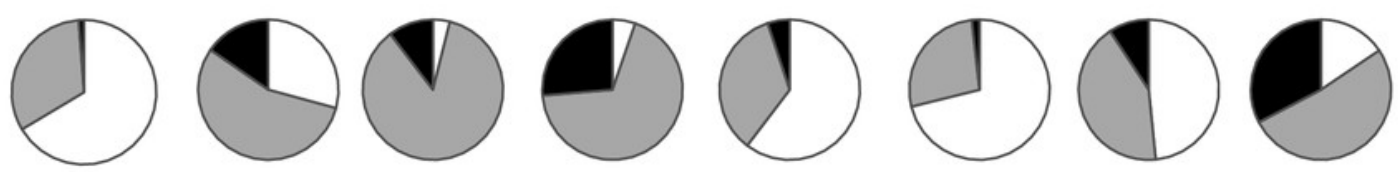

$\square<1 \mathrm{~cm} \quad \square 1-3 \mathrm{~cm} \quad \mathbf{a}>3 \mathrm{~cm}$ 


\section{Figure 2}

\section{Pictures of study sites}

(A) Cueva del Azufre chamber V (6 CV-2) and (B) site 7 CV-3. (C) El Azufre confluence with Clear Creek (1 EA-con) 


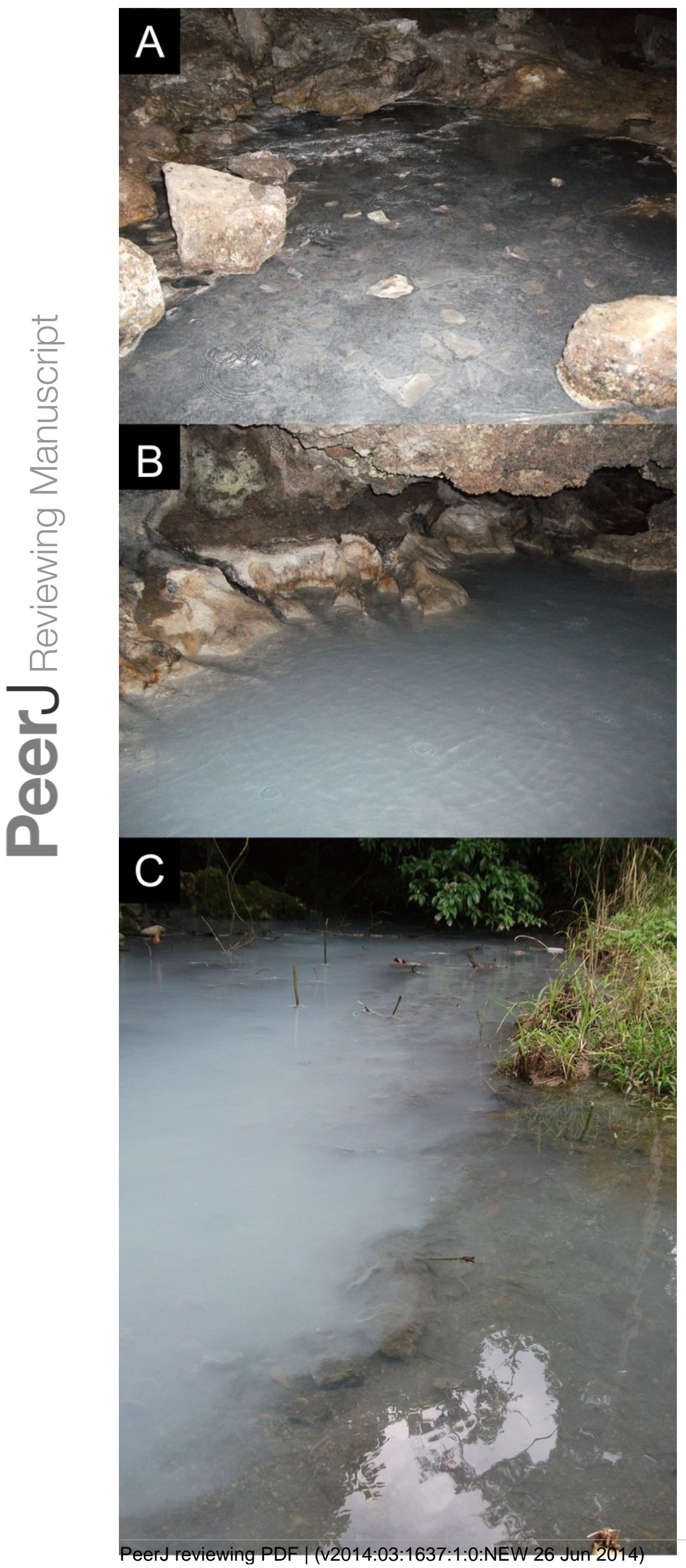




\section{Figure 3}

Exemplary sketch of site $5 \mathrm{CV}-1$

showing the high degree of heterogeneity in flow regimes, water depth, substrate types, and (in this case) light regime.

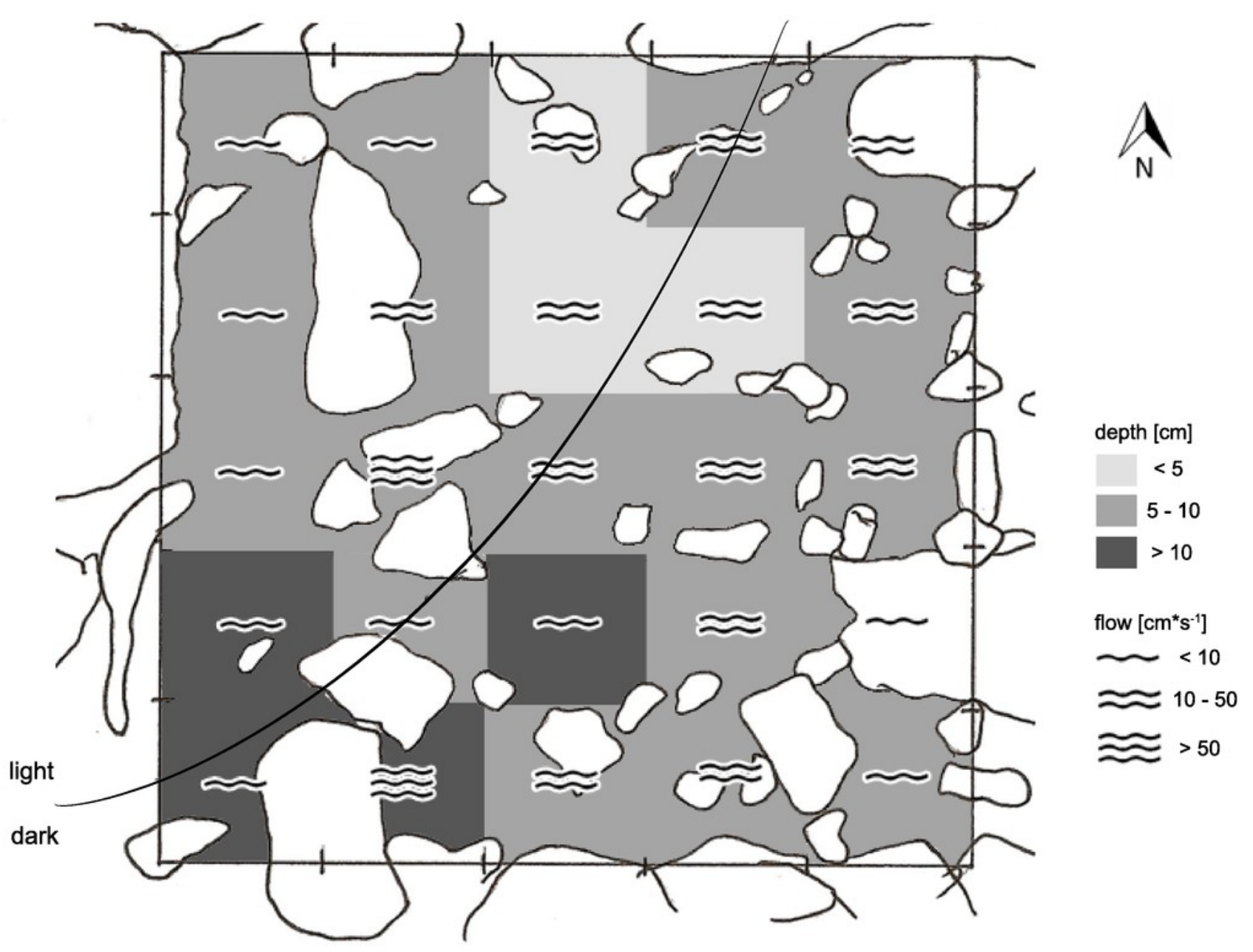




\section{Figure 4}

Differences in size-class compositions of Poecilia mexicana in the Cueva del Azufre system.

Non-metric Multi-Dimensional Scaling (NMDS) plots based on Bray-Curtis similarities for each sampling site and day.

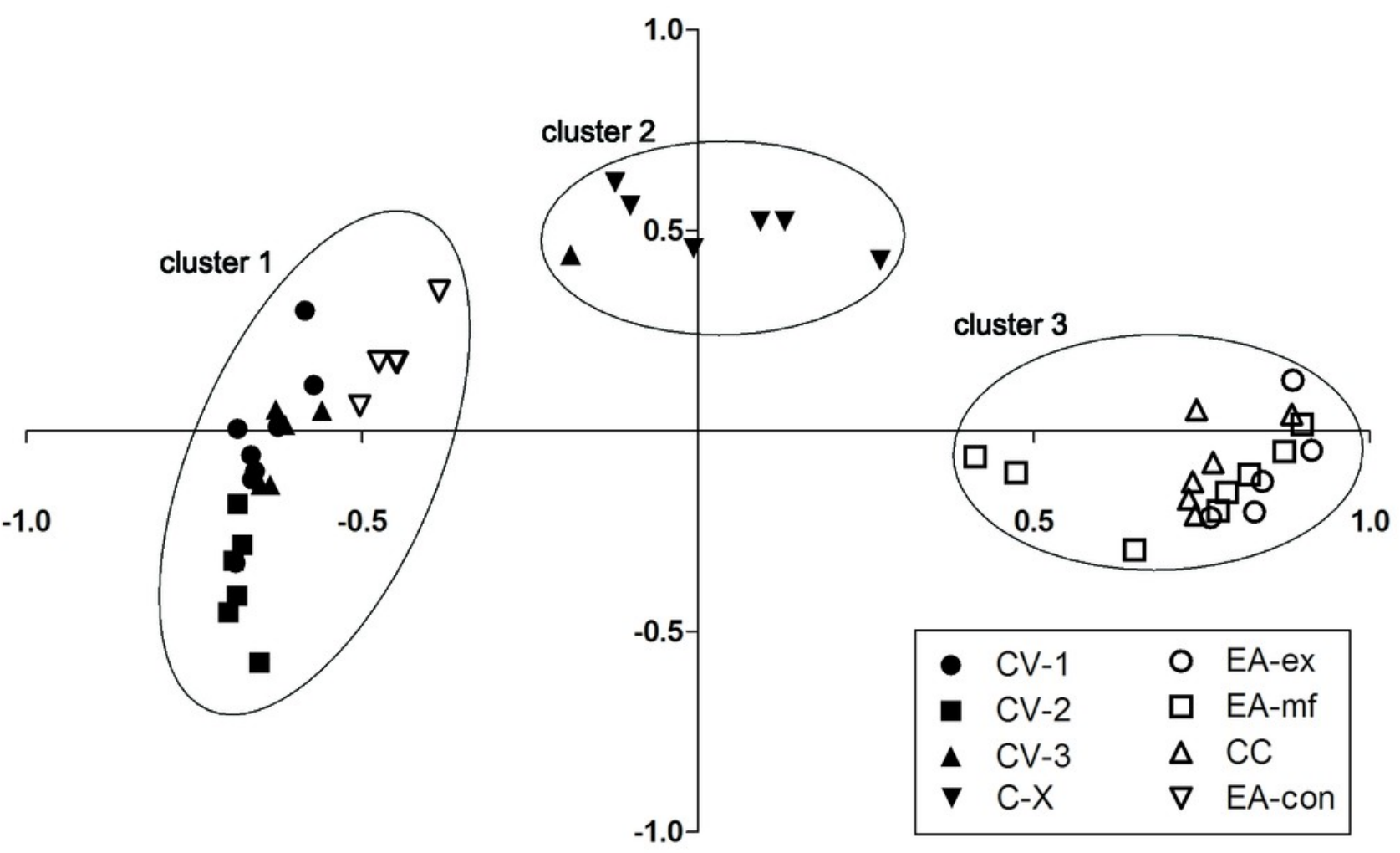




\section{Figure 5}

Population densities of cave mollies in the Cueva del Azufre.

Mean ( \pm SE) densities of mollies, categorized in three size classes $(<1 \mathrm{~cm}$, white, $1-3 \mathrm{~cm}$, gray, and $>3 \mathrm{~cm}$, black) in three water depths $(<5 \mathrm{~cm}, 5-10 \mathrm{~cm}$, and $>10 \mathrm{~cm})$. Results of rmGLMs are inserted. Note the different $y$-axis scales. Error bars are given if more than one sampling grid of a given depth class was present within the sampling site. 

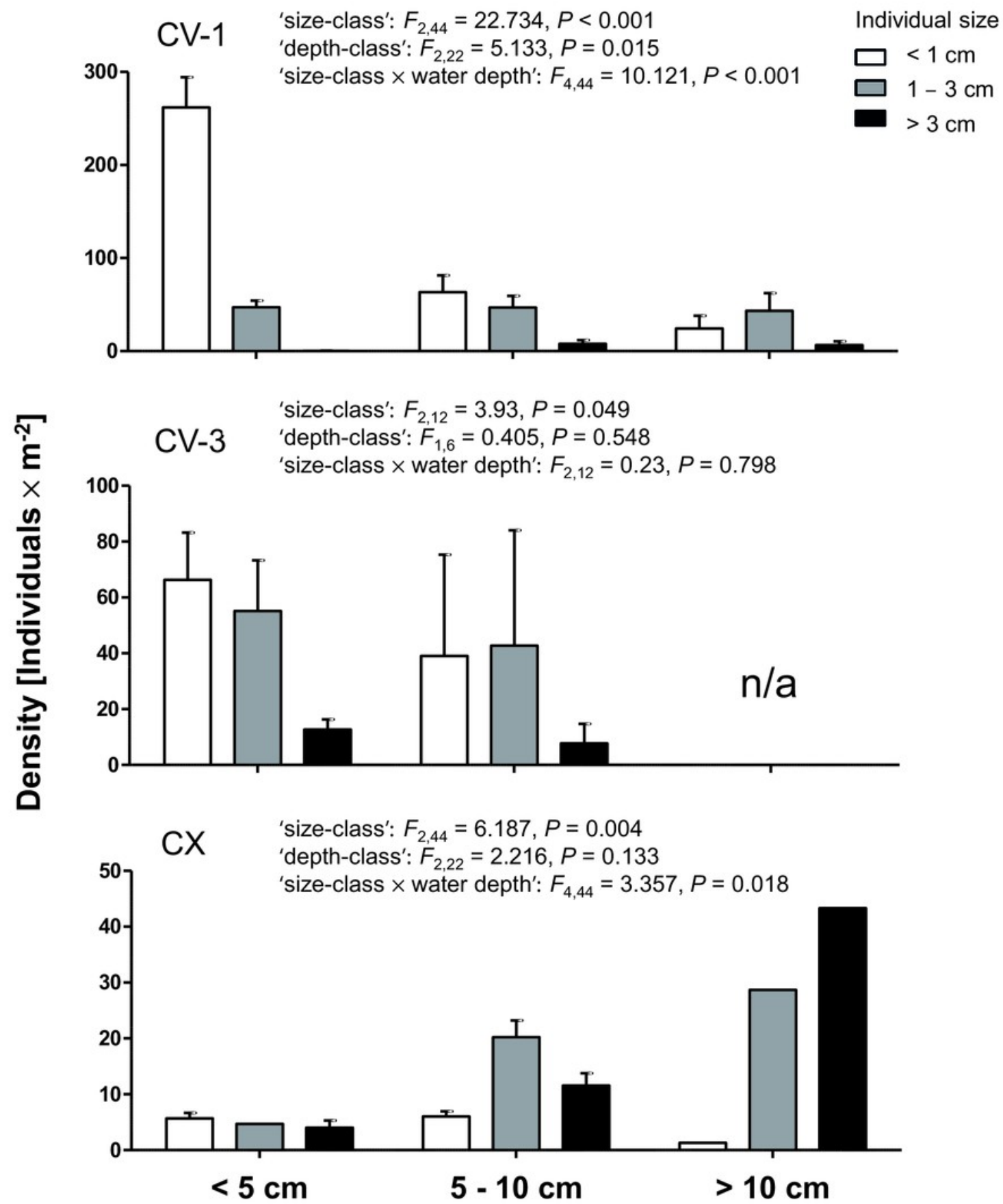

Water depth 